\title{
PENGARUH KEPEMILIKAN PUBLIK, UKURAN \\ PERUSAHAAN, UMUR LISTING, JUMLAH DEWAN \\ KOMISARIS INDEPENDEN DAN PROFITABILITAS \\ TERHADAP KETEPATAN WAKTU CORPORATE INTERNET \\ REPORTING PADA PERUSAHAAN SEKTOR KEUANGAN \\ YANG TERDAFTAR DI BURSA EFEK INDONESIA
}

\author{
Ayu Norfatmawati ${ }^{1}$, Djauhar Edi Purnomo ${ }^{2}$, Rini Hidayah ${ }^{3}$ \\ 1,2,3 Program Studi Akuntansi, Fakultas Ekonomika dan Bisnis \\ Universitas Muhammadiyah Pekajangan Pekalongan \\ Email : djauharedi@yahoo.com
}

\begin{abstract}
ABSTRAK
Penelitian ini bertujuan untuk menganalisis pengaruh kepemilikan publik, ukuran perusahaan, umur listing, jumlah dewan komisaris independen, dan profitabilitas terhadap ketepatan waktu corporate internet reporting pada perusahaan sektor keuangan yang terdaftar di Bursa Efek Indonesia. Sampel yang digunakan dalam penelitian ini adalah perusahaan sektor keuangan yang terdaftar di Bursa Efek Indonesia dengan teknik pengumpulan data yang digunakan dalam penelitian ini menggunakan purposive sampling sebanyak 50 sampel perusahaan yang memenuhi kiteria penelitian. Pengumpulan data dilakukan dengan menggunakan data sekunder melalui website resmi Bursa Efek Indonesia. Alat analisis yang digunakan dalam penelitian ini adalah analisis regresi logistik dengan menggunakan program Microsoft Excel dan SPSS 16.

Hasil penelitian ini menunjukkan bahwa secara parsial variabel kepemilikan publik, umur listing, jumlah dewan komisaris independen, dan profitabilitas tidak berpengaruh secara signifikan terhadap ketepatan waktu corporate internet reporting. Sedangkan variabel ukuran perusahaan berpengaruh secara signifikan terhadap ketepatan waktu corporate internet reporting. Dan secara simultan bahwa variabel kepemilikan publik, ukuran perusahaan, umur listing, jumlah dewan komisaris independen, dan profitabilitas berpengaruh secara signifikan terhadap ketepatan waktu corporate internet reporting.
\end{abstract}

Kata kunci : Kepemilikan Publik, Ukuran Perusahaan, Umur Listing, Jumlah Dewan Komisaris Independen, Profitabilitas, Ketepatan Waktu Corporate Internet Reporting. 


\section{ABSTRACT}

This research aims to determine and analyze the effect of public ownership, company size, age of listings, number of independent commissioners, and profitability on the timeliness of corporate internet reporting in financial sector companies listed on the Indonesia Stock Exchange. The sample used in this study is financial sector companies listed on the Indonesia Stock Exchange with the sample collection technique used purposive sampling with the amount of final sample to 50 companies that meet the criteria. The data used are secondary data from the official page on the Indonesia Stock Exchange. The analytical tool used in this study is logistic regression analysis using Microsoft Excel and SPSS 16.

The result of this study indicate that partially the variable of public ownership, age of listings, number of independent commissioners, and profitability has no effect on the timeliness of corporate internet reporting. While the company size have a significant effect on the timeliness of corporate internet reporting. And the simultaneously that the variable of public ownership, company size, age of listings, number of independent commissioners, and profitability have a significant effect on the timeliness of corporate internet reporting.

Keywords : Public Ownership, Company Size, Age of Listings, Number of Independent Commissioners, and Profitability, Timeliness of Corporate Internet Reporting.

\section{PENDAHULUAN}

Selama beberapa tahun terakhir, jumlah pengguna internet di Indonesia meningkat berdasarkan hasil survey Asosiasi Penyelenggara Jasa Internet Indonesia atau APJII (2020) bahwa jumlah pengguna internet di Indonesia pada periode 2019 sampai dengan periode 2020 kuartal II mengalami kenaikan menjadi 73,7 persen dari populasi di Indonesia. Jumlah ini setara dengan 196,7 juta pengguna internet dengan populasi Republik Indonesia sebesar 266,9 juta jiwa. Jumlah tersebut mengalami kenaikan sebesar 8,9 persen yang setara dengan 25,5 juta pengguna internet dari tahun lalu.

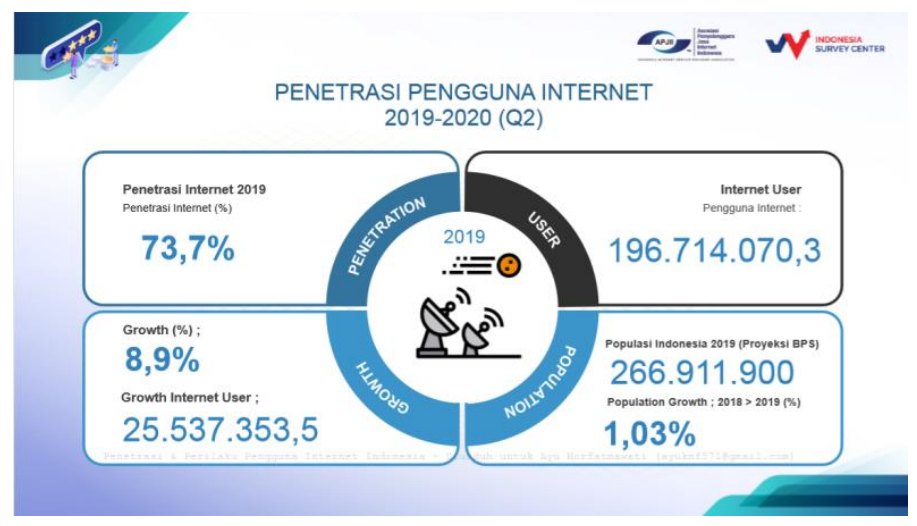

\section{Gambar 1 Hasil Survei APJII Pengguna Internet di Indonesia 2019-2020 Kuartal II}


Kenaikan jumlah pengguna internet tersebut disebabkan beberapa faktor seperti infrastruktur internet yang sangat cepat dan hemat. Karena peningkatan yang signifikan dalam pengguna internet ini, semakin banyak bisnis di Indonesia yang menggunakan internet sebagai alat komunikasi dan untuk menjalankan tugas-tugas seperti pelaporan keuangan melalui internet. Munculnya internet sebagai model komunikasi tercepat dan terluas membuat perusahaan mulai melaporkan informasi pribadinya di website perusahaan. Laporan keuangan yang biasanya dicetak di atas kertas, kini disampaikan melalui internet seperti corporate internet reporting.

Di Indonesia, pertumbuhan ekonomi ditandai dengan peningkatan jumlah perusahaan yang go public setiap tahunnya. Mengutip dari laman www.idx.co.id bahwa jumlah perusahaan yang go public pada tahun 2019 berjumlah 677 perusahaan, hingga tahun 2020 mencapai 722 perusahaan. Peningkatan jumlah perusahaan yang go public memberikan peluang bagi calon investor untuk menanamkan modalnya di pasar modal. Semakin banyaknya perusahaan yang go public di Indonesia menandakan adanya peluang yang dapat dimanfaatkan perusahaan untuk menarik investor dalam perkembangan perusahaan.

Melansir dari laman IDN Financial (2020) bahwa pada QI 2020 tercatat 46 perusahaan belum menyampaikan laporan keuangan, diantaranya 43 perusahaan didenda oleh bursa, 1 perusahaan yang sedang melakukan peninjauan terbatas pada laporan keuangan, serta 2 perusahaan sedang menyerahkan laporan keuangannya untuk diaudit akuntan publik. Selain adanya kasus keterlambatan dalam pengungkapan pelaporan keuangan perusahaan. Perusahaan sektor keuangan juga mengalami kasus gagal bayar yang terjadi di perusahaan-perusahaan asuransi besar seperti Grup Kresna Graha Investama. Berdasarkan laporan dari CNBC Indonesia (2020) mengatakan bahwa Grup Kresna Graha Investama menjadi sorotan publik akibat tiga anak usahanya gagal bayar manfaat dibisnis asuransi jiwa. Ketiga anak usahanya tersebut yaitu PT Asuransi Jiwa Kresna, PT Kresna Asset Management, PT Kresna Sekuritas. Ketiganya di bawah kendali holding bisnis PT Kresna Graha Investama Tbk dengan kode saham KREN. PT Asuransi Jiwa Kresna atau Kresna Life mengalami kasus gagal bayar dua produk asuransinya, seperti Krena Link Investa (K-LITA) dan Protecto Investa Krena (PIK). Atas kasus gagal bayar yang dialami PT Kresna Graha Investama Tbk, maka Otoritas Jasa Keuangan melakukan tindakan pengawasan seperti mewajibkan Kresna Life untuk membayar klaim yang telah diajukan oleh pemegang polis. 


\section{TINJAUAN PUSTAKA}

Agency theory atau teori keagenan mendiskripsikan hubungan antara pemegang saham sebagai principal dan manajemen perusahaan sebagai agent. Pihak manejemen atau agent merupakan pihak yang dikontrak oleh pemegang saham untuk bekerja demi kepentingan pemegang saham. Agency theory berfungsi untuk menganalisa serta menemukan solusi terhadap masalah yang ada dalam hubungan keagenan antara manajemen dan pemegang saham (Hendrawaty, 2017, hal. 28). Masalah keagenan dapat timbul akibat perbedaan kepentingan antara pihak manajemen dan pemegang saham. Semakin banyak jumlah pemegang saham perusahaan, maka semakin sulit pengawasan saham perusahaan yang dilakukan oleh pihak manajemen. Hal tersebut yang menimbulkan masalah keagenan yang dapat berdampak pada biaya keagenan.

Ketepatan waktu corporate internet reporting merupakan proses yang dilakukan oleh perusahaan yang melaporkan keuangannya melalui internet di website yang dimiliki oleh perusahaan atau di Bursa Efek Indonesia, hal tersebut menjadi kewajiban setiap perusahaan untuk memberikan informasi secara terbuka kepada publik. Pelaporan keuangan melalui internet muncul dan berkembang sebagai alat media tercepat untuk menginformasikan hal-hal yang berkaitan dengan perusahaan. Kecenderungan pihak manajemen untuk menentukan bagaimana memaksimalkan tujuan perusahaan dalam mengungkapkan pelaporan perusahaan melalui internet sebagai media bagi perusahaan untuk menyampaikan segala informasi pertanggungjawabannya kepada pihak eksternal sesuai dengan kontrak keagenan yang diinginkan (Syahputri \& Kananto, 2020).

Kepemilikan saham perusahaan yang diwakili oleh saham yang diperdagangkan di pasar terbuka, baik di pasar modal maupun di pasar bebas. Pemegang saham individu dan institusional masing-masing memiliki bagian dari kepemilikan publik, sebanding dengan jumlah saham yang mereka miliki sebagai presentase dari semua saham yang beredar. Dengan demikian, pemegang saham memiliki keputusan akhir dalam semua keputusan yang dibuat oleh perusahaan dan manajernya, terutama melalui rapat pemegang saham tahunan. Kepemilikan publik memungkinkan perusahaan memiliki akses yang lebih besar ke pembiayaan dari pada perusahaan lain, karena mereka memiliki kemampuan untuk menerbitkan lebih banyak saham.

Ukuran perusahaan merupakan suatu skala yang dapat diklasifikasikan dari besar kecilnya perusahaan dengan melihat total aset atau total penjualan, kapasitas pasar, jumlah tenaga kerja yang dimiliki oleh perusahaan. Ukuran perusahaan dapat menunjukkan seberapa besar 
informasi penting yang terdapat di dalamnya serta mencerminkan kesadaran dari pihak manajemen terkait pentingnya informasi, baik bagi pihak internal maupun pihak eksternal perusahaan. Perusahaan yang berukuran besar memiliki jumlah pemegang kepentingan saham lebih luas sehingga berbagai kebijakan perusahaan besar akan menimbulkan dampak lebih besar terhadap kepentingan publik dibandingkan dengan perusahaan kecil.

Umur listing merupakan umur suatu perusahaan yang telah terdaftar di Bursa Efek Indonesia. Perusahaan yang ingin mendaftarkan di Bursa Efek Indonesia melakukan penawaran saham untuk pertama kalinya yang dinamakan dengan Initial Public Offering atau yang biasa disebut IPO. Peraturan Nomor 29/POJK.04/2016 tentang penyampaian laporan tahunan emiten atau perusahaan yang menjelaskan bahwa perusahaan yang akan mendaftar dan yang sudah mendaftarkan perusahaannya memiliki kewajiban untuk melakukan pelaporan keuangan.

Dewan komisaris independen merupakan anggota komisaris yang berasal dari luar emiten atau perusahaan publik, tidak mempunyai saham baik langsung maupun tidak langsung dengan emiten atau perusahaan publik. Jumlah dewan komisaris independen berdasarkan aturan Peraturan Otoritas Jasa Keuangan Nomor 33/POJK.04/2014 minimal 30 persen dari seluruh anggota dewan komisaris.

Profitabilitas suatu perusahaan mencerminkan tingkat keuntungan yang dicapai oleh suatu perusahan. Profitabilitas merupakan kemampuan suatu perusahaan untuk menggunakan sumber dayanya untuk menghasilkan pendapatan yang melebihi biayanya. Dengan kata lain, profitabilitas adalah kemampuan perusahaan menghasilkan keuntungan dari operasinya. Profitabilitas merupakan salah satu rasio untuk menganalisis laporan keuangan dan kinerja perusahaan secara keseluruhan. Investor, kreditor dan manajer menggunakan konsep ini untuk menganalisis seberapa baik kinerja perusahaan dan potensi di masa depan jika operasi dikelola dengan baik.

\section{METODE PENELITIAN}

Populasi pada penelitian ini yaitu perusahaan sektor keuangan yang terdaftar di Bursa Efek Indonesia tahun 2018, 2019 dan 2020. Perusahaan sektor keuangan dijadikan objek penelitian ini karena mempunyai peranan strategis dalam kegiatan perekonomian seperti menghimpun dan menyalurkan dana masyarakat secara efektif dan efisien. Oleh karena itu, perusahaan sektor keuangan memiliki tanggung jawab moral yang lebih dalam melaporkan kinerja keuangannya ke masyarakat luas. Analisis yang digunakan pada penelitian ini menggunakan analisis regresi logistik. 
Pengambilan sampel dalam penelitian ini menggunakan teknik purposive sampling, dimana populasi yang akan dijadikan sampel penelitian akan memenuhi kriteria tertentu. Dalam penentuannya diterapkan kriteria sebagai berikut :

3.1. Perusahaan sektor keuangan yang terdaftar di Bursa Efek Indonesia tahun 2018, 2019 dan 2020

3.2. Perusahaan yang menerbitkan laporan tahunan atau annual report tahun 2018, 2019 dan 2020

3.3. Perusahaan sektor kuangan dengan indeks papan utama di bursa saham.

4. HASIL DAN PEMBAHASAN

Variables in the Equation

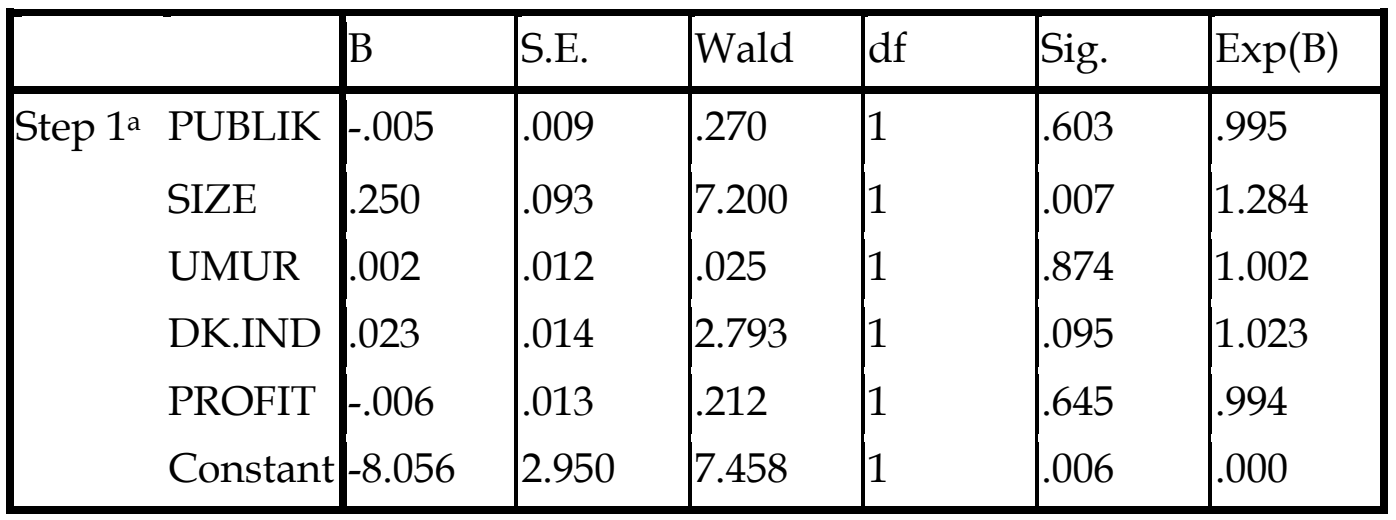

a. Variable(s) entered on step 1: PUBLIK, SIZE, UMUR, DK.IND, PROFIT.

\subsection{Hipotesis Pertama (H1)}

Kepemilikan publik tidak berpengaruh secara signifikan terhadap ketepatan waktu corporate internet reporting. Hal ini dapat dibuktikan dengan nilai signifikansi kepemilikan publik sebesar 0,603 > 0,05 sehingga dapat disimpulkan $\mathrm{H} 1$ ditolak.

4.2.Hipotesis Kedua (H2)

Pada variabel ukuran perusahaan berpengaruh secara signifikan terhadap ketepatan waktu corporate internet reporting. Hal ini dapat dibuktikan dengan nilai signifikansi ukuran perusahaan sebesar 0,007 < 0,05 sehingga dapat disimpulkan $\mathrm{H} 2$ diterima.

4.3.Hipotesis Ketiga (H3)

Umur listing tidak berpengaruh secara signifikan terhadap ketepatan waktu corporate internet reporting. Hal ini dapat dibuktikan dengan nilai signifikansi umur listing sebesar 0,874>0,05 sehingga dapat disimpulkan $\mathrm{H} 3$ ditolak.

4.4.Hipotesis Keempat (H4)

Jumlah dewan komisaris independen tidak berpengaruh secara signifikan terhadap ketepatan waktu corporate internet reporting. Hal ini 
dapat dibuktikan dengan nilai signifikansi jumlah dewan komisaris independen sebesar 0,095 > 0,05 sehingga dapat disimpulkan H4 ditolak.

4.5.Hipotesis Kelima (H5)

Profitabilitas tidak berpengaruh secara signifikan terhadap ketepatan waktu corporate internet reporting. Hal ini dapat dibuktikan dengan nilai signifikansi profitabilitas sebesar $0,645>0,05$ sehingga dapat disimpulkan $\mathrm{H} 5$ ditolak.

\section{KESIMPULAN DAN SARAN}

\subsection{Kesimpulan}

Bahwa dalam penelitian ini variabel kepemilikan publik (x1), umur listing (x3), jumlah dewan komisaris independen (x4), dan profitabilitas (x5) tidak berpengaruh secara signifikan terhadap ketepatan waktu corporate internet reporting. Sedangkan untuk variabel ukuran perusahaan $(\mathrm{x} 2)$ berpengaruh secara signifikan terhadap ketepatan waktu corporate internet reporting.

\subsection{Saran}

5.2.1. Untuk penelitian selanjutnya, peneliti menyarankan untuk memperluas sampel penelitian baik dengan menambahkan periode penelitian ataupun menggunakan seluruh perusahaan yang terdaftar di Bursa Efek Indonesia. Sehingga memungkinkan memperoleh kondisi yang sebenarnya.

5.2.2. Untuk penelitian selanjutnya, peneliti menyarankan untuk yang akan meneliti tentang ketepatan waktu corporate internet reporting agar menambahkan variabel yang dapat mempengaruhi ketepatan waktu corporate internet reporting seperti likuiditas, opini auditor, leverage, dan jumlah direksi.

\section{PUSTAKA}

Afriyeni, \& Marlius, D. (2018). Analisis Faktor-Faktor Yang Berpengaruh Terhadap Ketepatan Waktu Corporate Internet Reporting Pada Perusahaan Yang Listing Di Bursa Efek Indonesia . Jurnal Ilmiah, 1-17.

Aggradita, D., \& Nazar, M. R. (2019). Pengaruh Likuiditas, Profitabilitas, dan Corporate Governance Terhadap Ketepatan Waktu Pelaporan Keuangan. e-Proceeding of Management, 3418-3425.

APJII, B. (2020, 11 9). Siaran Pers: Pengguna Internet Indonesia Hampir Tembus 200 Juta di 2019 - Q2 2020. Dipetik 2 9, 2021, dari Asosiasi Penyelenggara Jasa Internet Indonesia: https://blog.apjii.or.id/index/php/2020/22/09/siaran-pers-penggunainternet-indonesia-hampir-tembus-200-juta-di-2019-q2-2020,

Ardiastuti, Y., Widarno, B., \& Harimurti, F. (2019). Analisis Faktor Yang Mempengaruhi Pelaporan Keuangan Perusahaan Melalui Internet. Jurnal Ilmiah, 609-620. 
Arlinda, P. S. (2018). Pengaruh Rasio Aktivitas, Leverage, Profitabilitas, dan Rasio Pertumbuhan Perusahaan Terhadap Ketepatan Waktu Corporate Internet Reporting Pada Perusahaan Yang Terdaftar Di BEI Tahunn 2016. Jurnal Ilmiah, 1-17.

Aulia Hunowu, R. R. (2019). Pengaruh Ukuran Perusahaan, Leverage, Kepemilikan Saham Publik, dan Profitabilitas Terhadap Corporate Internet Reporting. Jurnal Ilmiah, 1-17.

E Janros, V. S., \& Prima, A. P. (2018). Analisis Faktor-Faktor Yang Mempengaruhi Ketepatan Waktu Pelaporan Keuangan (Studi Pada Perusahaan Perbankan Yang Terdaftar Di BEI). Jurnal Akuntansi Keuangan dan Bisnis, 61-68.

Ekadinanti, N. S., \& Khairunnisa. (2020). Pengaruh Kepemilikan Instituasional, Kepemilikan Manajemen dan Leverage Terhadap Ketepatan Waktu Laporan Keuangan. E-Procceding of Management, 373-379.

Ernawati, \& Fayiatha, H. (2019). Pengungkapan Informasi Keuangan melalui Internet Oleh Perusahaan Besar Di Indonesia. Global Financial Accounting Journal, 1-16.

Fadhilah Sandy, M. F. (2019). Pengaruh Kepemilikan Publik, Ukuran Perusahaan, Umur Listing dan Jumlah Dewan Komisaris Independen Terhadap Ketepatan Waktu Corporate Internet Reporting. Jurnal Ilmiah, $1-79$.

Gafar, A., Malisan, L., \& Irwansyah. (2017). Faktor-Faktor Yang Mempengaruhi Ketepatan Waktu Penyampaian Laporan Keuangan Pada Perbankan Yang Terdaftar Di Bursa Efek Indonesia. Forum Ekonomi, 42-52.

Gaol, L., \& Tiuriana, I. (2019). Pengaruh Total Aktiva, Komite Audit, Ukuran Perusahaan, dan Ukuran KAP Terhadap Ketepatan Waktu Pada Perusahaan Sektor Keuangan Yang Terdaftar Di Bursa Efek Indonesia. Jurnal Ilmiah, 1-42.

Hastuti, R. K. (2020, Agustus 16). Kacau! Gagal Bayar 5 Asuransi Ini Bikin Nasabah Teriak. Dipetik Februari 26, 2021, dari CNBC Indonesia: https://www.cnbcindonesia.com/market/20200816100319-17180132/kacau-gagal-bayar-5-asuransi-ini-bikin-nasabah-teriak

Hendrawaty, E. (2017). Excess Cash Dalam Perspektif Teori Keagenan. Bandar Lampung: AURA Anugrah Utama Raharja.

Ikhsan, H. N. (2017). Analisis Pengaruh Ukuran Perusahaan, Kepemilikan Publik, dan Umur Listing Terhadap Ketepatan Waktu Corporate Internet Reporting Pada Perbankan di Bursa Efek Indonesia Periode 2014-2016. Jurnal Ilmiah, 1-58.

Indiyani, N. (2019). Pengaruh Profitabilitas, Ukuran Perusahaan, Likuiditas, dan Kepemilikan Publik Terhadap Ketepatan Waktu Corporate Internet Reporting. Artikel Ilmiah, 59-78.

Indonesia Stock Exchange Building. (2020). Pengumuman Penyampaian Laporan Keuangan Auditan yang Berakhir per 31 Maret 2020. Jakarta: https://www.idx.co.id. 
Indonesia, M. (2019, Januari 28). Peran Sektor Keuangan Perlu Diperkuat. Dipetik Maret 5, 2021, dari Media Indonesia: https://m.mediaindonesia.com/ekonomi/213378/peran-sektorkeuangan-perlu-diperkuat

KR. (2020, Agustus 11). Telat Umumkan Laporan Keuangan, 443 Emiten Didenda Bursa Efek Indonesia. Dipetik februari 10, 2021, dari IDN Financial: http://idnfinancial.com/id/news/35667/companies-fined-idx-latefinancial-report-disclosure

Kusuma, C. L. (2019). Ukuran Perusahaan, Profitabilitas, Umur Perusahaan dan Leverage Terhadap Corporate Internet Reporting. Jurnal Ilmiah, 1-16.

Otoritas Jasa Keuangan. (2016). Peraturan Otoritas Jasa Keuangan Nomor 29/POJK.04/2016. Jakarta: Otoritas Jasa Keuangan Republik Indonesia.

Prihadi, T. (2019). Analisis Laporan Keuangan Konsep \& Aplikasi . Jakarta: PT Gramedia Pustaka Utama.

Safitri, R. D. (2018). Analisis Pengaruh Mekanisme Corporate Governance Terhadap Ketepatan Waktu Corporate Internet Reporting. Jurnal Ilmiah, 1-14.

Septarian, D. (2017). Pengaruh Ukuran Perusahaan, Komite Audit, dan Kepemilikan Publik Terhadap Ketepatan Waktu Corporate Internet Reporting. Jurnal Ilmiah, 1-18.

Susanto, A. (2018). Pengaruh Karakteristik Perusahaan Dan Corporate Governance Terhadap Ketepatan Waktu Corporate Internet Reporting. Parsimonia, 233-246.

Syahputri, L. L., \& Kananto. (2020). Analisis Faktor-Faktor Yang Mempengaruhi Ketepatan Waktu Corporate Internet Reporting. Jurnal Ilmiah, 1-15.

Wahyu Krisnanda, I. G., \& Dwi Ratnadi, N. M. (2017). Pengaruh Financial Distress, Umur Perusahaan, Audit Tenure, Kompetensi Dewan Komisaris Terhadap Ketepatan Waktu Corporate Internet Reporting. Jurnal Akuntansi Universitas Udayana, 1933-1960.

Wareza, M., \& Sidik, S. (2020, Agustus 19). Gagal Bayar, Suspensi, hingga Digugat, Ada Apa Dengan Kresna. Dipetik Maret 14, 2021, dari CNBC Indonesia: http://www.cnbc.com/market/20200819135419-17-180846/gagal-bayarsuspensi-hingga-digugat-ada-apa-dengan-kresna

Widhiyawati, R. (2021). Determinan Ketepatan Waktu Pelaporan Keuangan Pada Perusahaan Perbankan Yang Listing Di Bursa Efek Indonesia. Jurnal Ilmiah, 1-17.

Widyasari, P. A., \& Kurniawan, E. C. (2020). Pengaruh Pelaporan Keuangan Melalui Internet Dan Tata Kelola Pada Kesulitan Keuangan di Sektor Perbankan. Jurnal Akuntansi, 165-182.

Zenniar, A. O., \& Alit Triani, N. N. (2018). Pengaruh Konsentrasi Kepemilikan Saham dan Leverage Terhadap Pelaporan Keuangan Pada Perusahaan Sektor Keuangan di Bursa Efek Indonesia. Jurnal Ilmiah, 1-23. 